\title{
Penilaian tingkat keberhasilan perawatan ortodontik dengan piranti lepasan berdasarkan indeks PAR Assessment of success rate of orthodontic treatment using removable appliance based on PAR index
}

\author{
${ }^{1}$ Muh. Irwansyah, ${ }^{2}$ Eka Erwansyah \\ ${ }^{1}$ Mahasiswa Tahapan Profesi \\ ${ }^{2}$ Bagian Ortodonsia \\ Fakultas Kedokteran Gigi Universitas Hasanuddin \\ Makassar, Indonesia
}

\begin{abstract}
The success of orthodontic treatment, particularly with removable orthodontic appliances not only relies on the expertise of the clinician, but also highly depends on the patient's own. It is necessary to know the extent of the success rate of an orthodontic treatment. Assessment of malocclusion severity and treatment outcome has become a very popular object of research conducted by the PAR index. This study aims to determine the success rate of orthodontic treatment with removable appliances based on PAR Index. The research was carried out on March-May 2011 with samples of patients dental models who had completed orthodontic treatment in the year 2008-2011 at the Department of Ortodonsia RSGMP UNHAS. Sixty six pairs of dental models fulfilled the inclusion criteria and the rules of PAR Index. Percentage change in PAR score obtained by $35 \%$ in the assessment with no weighted and $36 \%$ was assessment by weighted. This results showed the level of orthodontic treatment success include into the category of "no change", but with a trend into the category of "a change "with a significant value $\rho=0.000$ ( $\rho<$ 0.05). It was concluded that there was occlusion improvements in orthodontic treatment with removable appliance, although very low and therefore need evaluation and improvement of governance maintenance carried out.
\end{abstract}

Keyword: PAR Index, orthodontic treatment, removable orthodontic appliance

\begin{abstract}
ABSTRAK
Keberhasilan perawatan ortodontik khususnya ortodontik lepasan selain bergantung pada keahlian diagnostik dari klinisi, juga sangat bergantung pada pasien itu sendiri. Untuk itu perlu diketahui tingkat keberhasilan suatu perawatan ortodontik. Penilaian tingkat keparahan maloklusi dan hasil perawatan telah menjadi objek penelitian yang sangat populer dilakukan dengan indeks PAR. Penelitian ini bertujuan untuk mengetahui tingkat keberhasilan perawatan ortodontik dengan piranti ortodontik lepasan berdasarkan Indeks PAR. Penelitian dilakukan pada bulan Maret-Mei 2011 dengan sampel berupa model gigi pasien yang telah selesai menjalani perawatan ortodontik pada tahun 2008-2011 di Klinik Ortodonsia RSGMP UNHAS. Diperoleh 66 pasang model gigi yang memenuhi kriteria inklusi dan aturan indeks PAR. Persentase perubahan skor PAR sebesar 35\% pada penilaian tanpa pembobotan dan $36 \%$ pada penilaian dengan pembobotan. Hal ini menunjukkan bahwa tingkat keberhasilan termasuk kategori "ada perubahan", namun cenderung masuk ke kategori "tidak ada perubahan" dengan nilai signifikan $\rho=0,000(\rho<$ $0,05)$. Disimpulkan bahwa terjadi perbaikan oklusi pada perawatan ortodontik dengan piranti lepasan, meskipun sangat kecil sehingga membutuhkan evaluasi dan perbaikan tatalaksana perawatan yang telah dilakukan.
\end{abstract}

Kata kunci: indeks PAR, perawatan ortodontik, piranti ortodontik lepasan

Koresponden: Eka Erwansyah, Bagian Ortodonsia, Fakultas kedokteran Gigi Universitas Hasanuddin, Jl. Kandea No.5 Makassar, Indonesia.E-mail: eka_ortho@yahoo.com

\section{PENDAHULUAN}

Maloklusi adalah bentuk oklusi gigi yang menyimpang dari normal. Oklusi dikatakan normal, jika susunan gigi dalam lengkung geligi teratur baik serta terdapat hubungan yang harmonis antara gigi atas dengan gigi bawah, hubungan seimbang antara gigi, tulang rahang terhadap tulang tengkorak dan otot sekitarnya yang dapat memberikan keseimbangan fungsional sehingga memberikan estetika yang baik. ${ }^{1}$ Proffit dkk menyatakan bahwa gigi berjejal, tidak teratur, dan gigi yang maju telah menjadi masalah bagi beberapa individu sejak zaman dahulu dan upaya untuk memperbaiki gangguan ini kembali setidaknya sampai 1000 SM. Selanjutnya seperti kedokteran gigi berkembang di abad ke-18 dan ke19 , sejumlah perangkat untuk pengaturan dari gigi digunakan oleh dokter gigi pada masa itu. ${ }^{2}$

Piranti ortodontik lepasan adalah salah satu macam piranti yang jamak digunakan untuk merawat maloklusi, selain piranti ortodontik cekat. Perawatan dengan piranti ortodontik diharapkan dapat mencapai susunan gigi yang teratur dan penampilan wajah yang harmonis. 
Menurut Isaacson dkk, dinyatakan bahwa piranti ortodontik lepasan adalah piranti yang pemakaiannya bisa dipasang dan dilepas oleh pasien, mempunyai kemampuan perawatan yang lebih sederhana dibanding dengan alat cekat, dianggap sebagai alat fungsional, karena alat ini hampir selalu dilepas. Piranti ini mempengaruhi otot-otot orofasial dan perkembangan dentoalveolar. $^{3}$

Pada perawatan ortodontik lepasan sering terjadi perubahan yang tidak diinginkan, biasanya setelah pemasangan alat akan terjadi perubahan yang lebih baik dari sebelumnya, namun setelah itu kemungkinan terjadi perubahan yang tidak diinginkan. Ada beberapa faktor yang mempengaruhinya, salah satu hal yang perlu diperhatikan bahwa faktanya gigi selalu cenderung untuk bergerak karena adanya gaya saat melakukan gerakan pengunyahan, apalagi saat seseorang masih dalam usia pertumbuhan (ratarata di bawah 17 tahun), tulang rahang terus bertumbuh dan posisi gigi mengikuti pertumbuhan tulang rahang.

Berdasarkan penelitian Powes dan Cook yang dikutip oleh Jazaldi dkk, dikatakan bahwa hasil perawatan ortodontik dapat dipengaruhi oleh beberapa hal, yaitu morfologi dan keparahan maloklusi, mekanoterapi perawatan ortodontik, pola pertumbuhan dan keterampilan operator. ${ }^{4}$

Sekundariadewi dkk menyatakan bahwa tujuan perawatan ortodontik adalah mencapai keseimbangan yang baik antara hubungan oklusi gigi geligi, estetik wajah, stabilitas hasil perawatan dan mempertahankan hasil perawatan ortodontik dalam waktu lama. Tujuan estetika dan oklusal gigi geligi dapat tercapai, tetapi stabilitas hasil perawatan ortodontik sampai sekarang masih menjadi masalah yang perlu diperhatikan. Pada penelitian Fox dan Cadwick yang dikutip oleh Sekundariadewi dkk ditemukan hasil perubahan nilai Indeks PAR sebesar $72 \%$ pada 100 kasus dalam kondisi setelah selesai perawatan ortodontik. $^{5}$

Penilaian keberhasilan perawatan ortodontik didasarkan pada diagnosis dan rencana perawatan yang lengkap. Diagnosis dan rencana perawatan maloklusi dilakukan berdasarkan pemeriksaan klinis, analisis model, analisis radiografis, profil dan wajah. Meskipun analisis model merupakan prosedur yang cukup menyita waktu, tetapi merupakan tahap yang terpenting dalam melakukan diagnosis karena banyak informasi yang diperoleh dari model cetakan gigi dalam memberikan gambaran tiga dimensi posisi gigi dalam mulut serta sangat membantu dalam merencanakan perawatan ortodontik. ${ }^{6}$

Penilaian seberapa jauh penyimpangan yang terjadi atau menilai keparahan suatu maloklusi tidaklah mudah. Untuk itu diperlukan pengalaman klinik dan pengetahuan yang luas mengenai oklusi. Meskipun demikian perbedaan persepsi antar individu tetap saja ada disebabkan adanya perbedaan kriteria penilaian, sehingga kemungkinan tetap ada unsur subjektif dalam menilai suatu keparahan maloklusi.

Menurut Richmond yang dikutip oleh Rahardjo, dinyatakankan bahwa penilaian keparahan maloklusi terus berkembang dan diupayakan agar mudah digunakan, akan tetapi tetap memberikan hasil yang objektif. Richmond memperkenalkan Peer Assessment Rating Index (PAR Index) untuk menilai keparahan maloklusi yang diharapkan dapat merupakan sarana untuk menentukan keparahan maloklusi secara objektif. Indeks PAR merupakan suatu nilai tunggal untuk semua anomali oklusi dan dapat digunakan untuk semua tipe maloklusi. ${ }^{7}$

Indeks PAR semakin banyak digunakan dalam studi menilai efektivitas perawatan ortodontik dalam praktik swasta dan studi klinik. Keuntungan indeks PAR dibanding dengan indeks ortodontik lainnya, adalah telah diterima secara universal dengan reliabilitas dan validitas yang sudah terbukti, ketepatan kriteria yang digunakan, metode kuantitatif yang objektif terhadap pengukuran maloklusi dan efektivitas hasil perawatan ortodontik.

Perawatan ortodontik di Bagian Ortodonsia Rumah Sakit Gigi dan Mulut Pendidikan Universitas Hasanuddin (RSGMP UNHAS) menggunakan alat ortodontik lepasan. Selama ini belum pernah dilakukan evaluasi tingkat keberhasilan perawatan ortodontik terhadap pasien yang telah selesai dirawat yang diukur dengan Indeks PAR. Di Indonesia, laporan ilmiah tentang penggunaan Indeks PAR pun masih sedikit ditemukan.

Berdasarkan latar belakang tersebut maka perlu diketahui tingkat keberhasilan perawatan ortodontik dengan piranti ortodontik lepasan di Bagian Ortodonsia RSGMP UNHAS terhadap keberhasilan perawatan ortodontik dengan menggunakan indeks PAR.

\section{BAHAN DAN METODE}

Penelitian ini bersifat observasional analitik yang pengambilan sampelnya dilakukan di Bagian Ortodonsia RSGMP UNHAS pada bulan Maret- 
Mei 2011. Sampel adalah model pasien yang telah selesai menjalani perawatan ortodontik dengan piranti ortodontik lepasan yang memenuhi kriteria inklusi, yaitu perawatan dengan piranti ortodontik lepasan, mempunyai model gigi yang kontras dan jelas sebelum dan setelah perawatan ortodontik, fase gigi permanen, dan semua jenis maloklusi yang ada di bagian Ortodonsia RSGMP UNHAS.

Bagian oklusi dievaluasi sebelum dan sesudah perawatan ortodontik berdasarkan indeks PAR. Indeks PAR memiliki 11 bagian yang meliputi, segmen anterior, kanan dan kiri atas, segmen posterior, kanan dan kiri bawah, overjet, overbite, garis median, oklusi bukal kanan dan kiri. Untuk setiap bagian, suatu penilaian tertentu telah ditentukan. Setelah diukur dan diberi skor yang spesifik untuk setiap bagian, skor dijumlah untuk setiap nilai sebelum dan sesudah perawatan ortodontik berdasarkan indeks PAR. Akan tetapi, karena skor total tidak cukup untuk mengevaluasi perbaikan oklusi dan pengobatan standar, komponen lain telah dipertimbangkan juga menurut Richmond dkk yang dikutip oleh Abtahi. ${ }^{8}$

Oleh karena itu, koefisien tertentu telah diberikan kepada segmen yang berbeda atas dasar studi Richmond sebagai berikut, segmen bukal kanan dan kiri: satu, segmen anterior mandibula dan oklusi bukal kanan dan kiri: satu, overjet: enam, overbite: dua, dan garis median: empat. Tingkatan yang dicapai untuk setiap segmen oklusi dikalikan dengan koefisien terkait dan hasil akhirnya ditemukan untuk setiap segmen. ${ }^{8}$

Data yang diperoleh selanjutnya dianalisis dengan menggunakan uji chi-square dan uji-t berpasangan dengan syarat jika tidak dipenuhi, maka dilanjutkan dengan uji Wilcoxon. Penurunan skor PAR antara model studi sebelum perawatan dan setelah perawatan ortodontik dihitung sebagai persentase dan nilai keseluruhan. Nilai $\rho<0,05$ dianggap signifikan secara statistik.

\section{HASIL}

Penelitian dilakukan di Bagian Ortodonsia RSGMP UNHAS pada bulan Maret-Mei tahun 2011. Dari 110 model gigi, didapatkan sampel sebanyak 66 pasang model gigi yang memenuhi kriteria inklusi dan aturan dari Indeks PAR. Terdapat 44 sampel yang tidak dapat dihitung dengan indeks PAR, karena berbagai kondisi, yaitu tidak adanya model gigi setelah perawatan ortodontik lepasan, model gigi yang rusak, dan ada satu gigi insisivus bawah yang telah dicabut. Karakteristik model pasien yang memenuhi kriteria inklusi terlihat pada tabel 1.

Tabel 1. Karakteristik sampel penelitian

\begin{tabular}{lcc}
\hline Jenis kelamin & n (\%) & Rentang usia \\
\hline Laki-laki & $10(15 \%)$ & 17,8 \\
Perempuan & $56(85 \%)$ & 20,4 \\
\hline
\end{tabular}

$\mathrm{n}=$ besar sampel

Analisis uji chi-square menunjukkan tidak terdapat hubungan $(\rho>0,05)$ antara usia dan jenis kelamin dengan hasil perawatan ortodontik lepasan, pada penilaian dengan tanpa pembobotan ataupun dengan pembobotan (tabel 2), dalam hal ini usia ataupun jenis kelamin secara khusus pada penelitian ini tidak ada hubungannya terhadap hasil suatu perawatan ortodontik khususnya ortodontik lepasan. Dengan demikian usia dan jenis kelamin dapat dikatakan homogen sehingga dimasukkan sebagai variabel terkendali dalam penelitian ini.

Tabel 2. Nilai hubungan usia dan jenis kelamin dengan hasil perawatan ortodontik lepasan

\begin{tabular}{|c|c|c|c|c|c|c|}
\hline & \multirow[t]{2}{*}{ Rerata } & \multirow[t]{2}{*}{$\mathrm{SD}$} & \multirow[t]{2}{*}{$\rho$ value (TP) } & \multirow[t]{2}{*}{$\rho$ value $(\mathrm{P})$} & \multicolumn{2}{|c|}{$\underline{\bar{X}}$ Perubahan } \\
\hline & & & & & $\mathrm{TP}$ & $\bar{P}$ \\
\hline Usia & 19,97 & 3,99 & 0,99 & 0,6 & 5,061 & 7,636 \\
\hline Jenis Kelamin & - & - & 0,07 & 0,565 & & \\
\hline
\end{tabular}

Tabel 3. Persentase perubahan nilai indeks PAR sebelum dan setelah perawatan ortodontik lepasan

\begin{tabular}{lccrcc}
\hline Nilai Indeks PAR & $\bar{X}$ Perubahan & $\bar{X} \%$ Perubahan & SD & $\rho$ value & Sig \\
\hline Sebelum perawatan (TP) & 14,455 & tanpa pembobotan & 7,3885 & 0,000 & $*$ \\
Setelah perawatan (TP) & 9,394 & $=35 \%$ & 5,4005 & & \\
Sebelum perawatan (P) & 20,909 & dengan pembobotan & 10,8794 & 0,000 & $*$ \\
Setelah Perawatan (P) & 13,273 & $=36 \%$ & 8,6283 & &
\end{tabular}

$\mathrm{TP}=$ tanpa pembobotan $; \mathrm{P}=$ dengan pembobotan; $\bar{X}$ perubahan $=$ rerata perubahan skor PAR; $\bar{X} \%$ perubahan = rerata persentase perubahan skor PAR; SD = standar deviasi; Sig = signifikan; ${ }^{*} \rho<0,05$ $\rightarrow$ Ada perbedaan bermakna nilai indeks PAR antara sebelum dan setelah perawatan ortodontik lepasan tanpa pembobotan dan dengan pembobotan. 
Tabel 4. Nilai distribusi sampel berdasarkan lama perawatan ortodontik lepasan dengan penilaian indeks PAR

\begin{tabular}{|c|c|c|c|c|c|c|}
\hline Lama Perawatan & $\mathrm{n}$ & T1 & $\mathrm{T} 2$ & $\bar{X}$ Perubahan & $\bar{X} \%$ Perubahan & $\rho$ value \\
\hline$<1$ tahun & 22 & & & & & \\
\hline Rerata (TP) & & 14,5 & 10,0 & 4,5 & $31 \%$ & \\
\hline Rerata $(\mathrm{P})$ & & 21,5 & 14,4 & 7,1 & $33 \%$ & \\
\hline$\geq 1$ tahun & 33 & & & & & $\mathrm{TP}=0,469$ \\
\hline Rerata (TP) & & 15,2 & 9,5 & 5,7 & $37,5 \%$ & $P=0,326$ \\
\hline Rerata (P) & & 21,4 & 12,9 & 8,5 & $39,7 \%$ & \\
\hline$\geq 2$ tahun & 11 & & & & & \\
\hline Rerata (TP) & & 12,1 & 8,0 & 4,1 & $33,9 \%$ & \\
\hline Rerata $(\mathrm{P})$ & & 18,5 & 12,2 & 6,3 & $34,1 \%$ & \\
\hline
\end{tabular}

$\mathrm{n}=$ jumlah sampel; $\mathrm{TP}=$ tanpa pembobotan; $\mathrm{P}=$ dengan pembobotan; $\mathrm{T} 1$ = sebelum perawatan; $\mathrm{T} 2=$ setelah perawatan; $\bar{X}$ perubahan $=$ rerata perubahan skor PAR; $\bar{X} \%$ perubahan $=$ rerata persentase perubahan skor PAR; $\rho>0,05 \rightarrow$ Tidak terdapat hubungan antara lama perawatan ortodontik lepasan dengan hasil perawatan ortodontik lepasan

Tabel 5. Nilai distribusi sampel berdasarkan kategori perubahan dalam perawatan ortodontik lepasan dengan penilaian Indeks PAR

\begin{tabular}{|c|c|c|c|c|c|}
\hline Kategori Perubahan & $\mathrm{n}$ & $\mathrm{T} 1$ & $\mathrm{~T} 2$ & $\bar{X}$ Perubahan & $\bar{X} \%$ Perubahan \\
\hline Tidak ada perubahan & 30 & & & & \\
\hline Rerata (TP) & & 13,4 & 12 & 1,4 & $10,4 \%$ \\
\hline Rerata (P) & & 18,1 & 17,3 & 0,8 & $4,4 \%$ \\
\hline Ada perubahan & 30 & & & & \\
\hline Rerata (TP) & & 15,3 & 8,2 & 7,1 & $46,4 \%$ \\
\hline Rerata (P) & & 21,9 & 11,6 & 10,3 & $47 \%$ \\
\hline Perubahan besar & 6 & & & & \\
\hline Rerata (TP) & & 15,3 & 3,5 & 11,8 & $77,1 \%$ \\
\hline Rerata (P) & & 22 & 3,3 & 18,7 & $85 \%$ \\
\hline
\end{tabular}

$\mathrm{n}=$ jumlah sampel; $\mathrm{TP}=$ tanpa pembobotan; $\mathrm{P}=$ dengan pembobotan; $\mathrm{T} 1$ = sebelum perawatan; $\mathrm{T} 2=$ setelah perawatan; $\bar{X}$ perubahan $=$ rerata perubahan skor PAR; $\bar{X} \%$ perubahan $=$ rerata persentase perubahan skor PAR

Nilai rerata indeks PAR sebelum dan setelah perawatan ortodontik lepasan, pada penilaian dengan tanpa pembobotan ataupun dengan pembobotan terdapat pada tabel 3. Didapatkan persentase perubahan antara sebelum dan setelah perawatan ortodontik lepasan pada penilaian dengan tanpa pembobotan sebesar 35\%, sedangkan pada penilaian dengan pembobotan didapatkan persentase perubahan sebesar $36 \%$. Dari hasil tersebut dapat diketahui bahwa perawatan ortodontik lepasan termasuk ke dalam kategori "ada perubahan", namun kecenderungan dalam kategori "tidak ada perubahan". Berdasarkan analisis uji-t berpasangan, tampak perbedaan bermakna $(\rho<0,05)$ antara nilai indeks PAR sebelum dan setelah perawatan ortodontik lepasan, pada penilaian dengan tanpa pembobotan ataupun dengan pembobotan.

Dari tabel 4 berdasarkan penilaian dengan tanpa pembobotan dan pembobotan pada jangka waktu kurang dari satu tahun, lebih dari 1 tahun dan lebih dari 2 tahun, dengan analisis uji chisquare ditunjukkan bahwa tidak terdapat hubungan $(\rho>0,05)$ antara lama perawatan ortodontik lepasan dengan hasil perawatan ortodontik lepasan, pada penilaian dengan tanpa pembobotan ataupun dengan pembobotan.

Berdasarkan tabel 5 untuk penilaian dengan tanpa pembobotan, didapatkan 6 sampel yang memiliki persentase perubahan $77,1 \%$ dan rerata perubahan 11,8 sehingga dikategorikan sebagai "perubahan besar". Sedangkan untuk penilaian dengan pembobotan, didapatkan persentase perubahan $85 \%$ yang memiliki rerata perubahan 18,7 mengalami penurunan skor PAR lebih besar atau sama dengan $70 \%$ sehingga dikategorikan sebagai "perubahan besar".

\section{PEMBAHASAN}

Pada penelitian ini, subjek adalah 66 model pasien yang telah selesai melakukan perawatan ortodontik lepasan di RSGMP UNHAS pada tahun 2008-2011. Subjek terdiri dari 10 laki-laki, lebih sedikit dibandingkan dengan perempuan, yaitu 56. Distribusi jenis kelamin ini sama seperti yang 
dilaporkan dalam penelitian lain, bahwa perempuan lebih banyak melakukan perawatan ortodontik dibandingkan dengan laki-laki. ${ }^{8-10}$ Banyaknya pasien perempuan dibandingkan dengan pasien laki-laki mungkin karena perempuan cenderung lebih memperhatikan estetik wajah daripada laki-laki sehingga mereka memilih perawatan ortodontik untuk mencapainya. Hal ini juga didukung oleh penelitian Onyeaso dkk ${ }^{11}$ yang melaporkan bahwa wanita lebih banyak melakukan perawatan keadaan maloklusinya dibandingkan laki-laki, karena merasa tidak nyaman dengan bentuk wajahnya.

\section{Usia dan jenis kelamin}

Dari hasil penelitian ini didapatkan bahwa tidak terdapat hubungan antara usia dan jenis kelamin dengan hasil perawatan ortodontik lepasan $(\rho>0,05)$. Namun Hal ini berbeda dengan temuan Kerr dkk yang dikutip oleh Birkeland $\mathrm{dkk}^{10}$ yang menemukan bahwa hasil perawatan ortodontik lepasan lebih baik pada jenis kelamin perempuan. Hal ini mungkin disebabkan perempuan memiliki kerjasama yang lebih baik dibandingkan pada laki-laki. Tidak adanya hubungan yang didapatkan pada penelitian ini, mungkin disebabkan oleh sangat terbatasnya jumlah sampel laki-laki.

\section{Lama perawatan}

Perawatan ortodontik dalam jangka waktu kurang atau sama dengan satu tahun menunjukkan persentase perubahan yang lebih besar dibandingkan dengan jangka waktu perawatan ortodontik lainnya, baik pada penilaian dengan tanpa pembobotan ataupun dengan pembobotan. Untuk mengetahui apakah ada hubungan antara lama perawatan dengan ortodontik lepasan dalam penelitian ini, maka dilakukan analisis statistik dengan menggunakan uji chi-square. Didapatkan bahwa tidak terdapat hubungan antara lama perawatan ortodontik lepasan dengan hasil perawatan ortodontik lepasan $(\rho>0,05)$ atau didapatkan nilai $\rho=0,469$ untuk penilaian dengan tanpa pembobotan dan nilai $\rho=0,326$ untuk penilaian dengan pembobotan. Hasil penelitian ini tidak sesuai dengan penelitian yang dilakukan oleh Bernas dkk $^{9}$ yang menyatakan bahwa terdapat korelasi positif tetapi kecil $(r=0,24, \mathrm{R} 2=$ $0,06)$ antara persentase penurunan skor PAR dan lama perawatan ortodontik. Perawatan ortodontik yang lebih lama menghasilkan penurunan skor PAR yang sedikit lebih besar.
Hal tersebut mungkin terjadi karena pasien tersebut memiliki kasus maloklusi yang ringan, sehingga tidak membutuhkan waktu yang lama dalam perawatan ortodontik. Namun, alasan mengapa hasil penelitian ini menunjukkan bahwa perawatan ortodontik yang lebih lama mendapatkan persentase perubahan yang sedikit, hal ini mungkin disebabkan karena kasus maloklusi yang dirawat di RSGMP UNHAS melibatkan kasus-kasus yang sulit, sehingga perawatan ortodontik dengan alat lepasan sulit untuk dilakukan.

\section{Perubahan skor PAR dan analisis hasil perawatan}

Dari hasil analisis uji t berpasangan untuk menguji perubahan nilai Indeks PAR sebelum dan setelah perawatan ortodontik didapatkan $\rho=0,000$ $(\rho<0,05)$, artinya ada perbedaan bermakna nilai indeks PAR antara sebelum dan setelah perawatan ortodontik lepasan, baik pada penilaian tanpa pembobotan dan dengan pembobotan. Adanya perbedaan yang bermakna antara sebelum dan setelah perawatan ortodontik secara statistik, menunjukkan bahwa secara umum terjadi perbaikan setelah perawatan ortodontik.

Oleh karena adanya variasi besar perubahan perawatan ortodontik, sehingga dilakukan pengkategorian berdasarkan persentase perubahan. "Tidak ada perubahan" untuk skor PAR yang mengalami penurunan kurang dari $30 \%$, "ada perubahan" untuk skor PAR yang mengalami penurunan lebih besar atau sama dengan 30\% dan "perubahan besar" untuk skor PAR yang mengalami penurunan lebih besar atau sama dengan 70\%. Dari penelitian ini, dilakukan perhitungan kategori perubahan berdasarkan penilaian dengan dan tanpa pembobotan. Dilakukannya pembobotan ini, karena menurut Richmond $\mathrm{dkk}^{12}$ skor dari hitungan kasar pada sampel tidak cukup untuk mengevaluasi perbaikan oklusi dan pengobatan standar, maka komponen lain harus dipertimbangkan juga.

Pada penelitian ini didapatkan hasil persentase perubahan adalah $35 \%$ pada penilaian dengan tanpa pembobotan, sedangkan pada penilaian dengan pembobotan didapatkan $36 \%$. Dapat dikatakan bahwa dari hasil perawatan ortodontik lepasan di RSGMP UNHAS, termasuk dalam kategori "ada perubahan" ( $\geq 30 \%-<70 \%)$. Namun, melihat besaran nilai perubahan yang sebesar $35 \%$ untuk penilaian dengan tanpa pembobotan dan $36 \%$ untuk penilaian dengan pembobotan, nilai ini mendekati ambang batas 
bawah untuk kategori "ada perubahan". Hal ini menunjukkan bahwa hasil penelitian ini memiliki kecenderungan tidak ada perubahan atau dengan kata lain perubahan yang terjadi sangat sedikit. Hal ini mungkin terjadi karena perawatan ortodontik melibatkan berbagai variasi keparahan maloklusi termasuk maloklusi kasus sulit.

Sebagai perbandingan adalah penelitian yang dilakukan oleh Richmond dkk ${ }^{12}$ bahwa dalam perawatan ortodontik lepasan didapatkan persentase perubahan sebesar $50,4 \%$ dari 48 sampel, termasuk ke dalam kategori "ada perubahan". Selain itu, penelitian yang dilakukan oleh Abtahi yang khusus meneliti hasil perawatan pada pasien klas II, mendapatkan persentase perubahan sebesar $34.07 \%$ dari 70 sampel yang juga termasuk ke dalam kategori yang sama. 8,10 Namun, nilai yang lebih tinggi diperoleh pada perawatan ortodontik cekat yang memiliki hasil perawatan ortodontik yang lebih baik dibandingkan dengan mengggunakan ortodontik lepasan. Berdasarkan penelitian Richmond $\mathrm{dkk}^{12}$ didapatkan persentase perubahan sebesar 71,4\% dari 196 sampel. Selain itu, penelitian yang dilakukan oleh Fox dan Chadwick juga mendapatkan persentase perubahan yang hampir sama yaitu sebesar 72\% dari 100 sampel dan hasil penelitian Birkeland dkk pun juga mendapatkan persentase perubahan yang hampir sama, yaitu sebesar $76,7 \%$. Semua hasil penelitian dengan perawatan ortodontik cekat ini termasuk ke dalam kategori "perubahan besar" yaitu hasil perawatan ortodontik yang mendapatkan persentase perubahan skor PAR lebih besar atau sama dengan $70 \%$. $^{5,10,12}$

Hal ini memperlihatkan perbedaan hasil pada kedua metode perawatan ortodontik tersebut dan perbedaan tingkat keahlian klinisi (spesialis ortodontik dan mahasiswa di klinik). Meskipun dalam institusi pengajaran bahwa banyaknya perawatan ortodontik yang dilakukan merupakan pengajaran yang bermanfaat, tetapi harus selalu diperlukan keahlian diagnostik dan penerapan kriteria yang lebih baik dari klinisi untuk meningkatkan keberhasilan perawatan ortodontik. Hasil ini menekankan pentingnya keahlian diagnostik dan pemeriksaan sebelum perawatan ortodontik pada kurikulum ortodontik di RSGMP UNHAS.

\section{SIMPULAN}

Berdasarkan hasil yang diperoleh pada penelitian ini, maka dapat disimpulkan bahwa terdapat perbedaan yang bermakna secara statistik dalam penurunan skor PAR antara sebelum dan setelah perawatan ortodontik lepasan, diperoleh persentase perubahan skor PAR sebesar 35\% untuk penilaian dengan tanpa pembobotan dan $36 \%$ untuk penilaian dengan pembobotan. Hal ini menunjukkan bahwa tingkat keberhasilan perawatan ortodontik lepasan di RSGMP UNHAS termasuk ke dalam kategori "ada perubahan."

\section{SARAN}

Berdasarkan fakta bahwa perubahan pada hasil perawatan sangat kecil atau memiliki kecenderungan masih dalam kategori "tidak ada perubahan", maka disarankan agar RSGMP UNHAS mencari cara dan usaha serta mungkin kebijakan untuk meningkatkan keberhasilan perawatan ortodontik lepasan. Untuk mencapai tujuan itu disarankan bahwa indeks PAR dapat digunakan dalam pemeriksaan sebelum perawatan ortodontik dan evaluasi hasil perawatan ortodontik.

\section{DAFTAR PUSTAKA}

1. Dewi O. Hubungan maloklusi dengan kualitas hidup pada remaja di kota Medan. Dentika Dent J 2009; 14(2): 115-6.

2. Proffit WR, Fields HW, Sarver DM. Contemporary orthodontics $4^{\text {th }}$ Ed. Philadelphia: Mosby Year Book Inc.; 1999, p. 2.

3. Isaacson KG, Muir JD, Reed RT. Removable orthodontic appliances. Oxford: Wright; 2002, p. 9.

4. Jazaldi F, Anggani HS, Purbiati M. Susunan gigi geligi hasil perawatan ortodonti berdasarkan objective grading system-american board of orthodontics. M. I. Kedokteran Gigi 2006; 21(3): 106.

5. Sekundariadewi R, Hoesin F, Widayati R. Evaluasi perubahan susunan gigi geligi pasca retensi perawatan ortodonti menggunakan Indeks PAR. M. I. Kedokteran Gigi 2007; 22(4): 147.

6. Budiman JA, Hayati R, Sutrisna B, Soemantri ES. Identifikasi bentuk lengkung gigi secara kuantitatif. Dentika Dent J 2009; 14(2): 120-1.

7. Rahardjo P. Penentuan derajat keparahan maloklusi dengan menggunakan Occlusal Index dan PAR Index. J Dent 2000; 229: Available from: URL: http://www/asic.lib.unair.ac.id/journals/abstrak/MK G 333 2000; Pambudi; Penentuan 2.pdf. Accesed 2010.

8. Abtahi SM. Evaluation of the outcome of removable orthodontic treatment performed by dental undergraduate student. Dent J Health 2009; 1(1): Available from http://www/ejo.oxfordjournals. org/content/19/3/279. full.pdf. Accessed 2010.

9. Bernas AJ, Banting DW, Short LL. Effectiveness of phase I orthodontic treatment in an undergraduate teaching clinic. J Dent Educ 2007; 71(9): 1179-86. 
10. Birkeland K, Furevik J, Boe OE, Wisth PJ. Evaluation of treatment and post-treatment changes by the PAR Index. Eur J Orthod 1997; 19: Available from: URL:http://www/djh.umsha.ac.ir/ upfile/76665Finalof Journal6. pdf. Accesed 2010.

11. Onyeaso CO, Utomi IL, Ibekwe TS. Emotional effect of malocclusion in Nigerian orthodontic. J
Contemp Dent Pract 2005; 6(1): 63.

12. Richmond S, Shaw WC, Roberts T, Andrews M. The PAR index (peer assessment rating): methods to determine outcome of orthodontic treatment in terms of improvement and standards. Eur J Orthod 1992; 14: 180-7. 